\title{
Communication \\ Seroepidemiology of Crimean-Congo Hemorrhagic Fever Virus (CCHFV) in Cattle across Three Livestock Pastoral Regions in Kenya
}

\author{
Isabel Blanco-Penedo ${ }^{1}\left(\mathbb{D}\right.$, Vincent Obanda ${ }^{2,3}$, Edward Kingori ${ }^{2,3}$, Bernard Agwanda ${ }^{4}$, Clas Ahlm ${ }^{5}$ \\ and Olivia Wesula Lwande ${ }^{5, *}$ \\ 1 Unit of Veterinary Epidemiology, Department of Clinical Sciences, Swedish University of Agricultural \\ Sciences, P.O. Box 7054, 75007 Uppsala, Sweden; isabel.blanco.penedo@slu.se \\ 2 Veterinary Services Department, Kenya Wildlife Service, Nairobi P.O. Box 40241-00100, Kenya; \\ vobanda@gmail.com (V.O.); kingmutee@gmail.com (E.K.) \\ 3 Department of Research Permitting and Compliance, Wildlife Research and Training Institute, P.O. Box 842, \\ Naivasha 20117, Kenya \\ 4 Mammalogy Section, National Museums of Kenya, Nairobi P.O. Box 40658-00100, Kenya; \\ benrisky@gmail.com \\ 5 Department of Clinical Microbiology, Umeå University, 90185 Umeå, Sweden; clas.ahlm@umu.se \\ * Correspondence: olivia.lwande@umu.se
}

check for updates

Citation: Blanco-Penedo, I.; Obanda, V.; Kingori, E.; Agwanda, B.; Ahlm,

C.; Lwande, O.W. Seroepidemiology of Crimean-Congo Hemorrhagic

Fever Virus (CCHFV) in Cattle across Three Livestock Pastoral Regions in Kenya. Dairy 2021, 2, 425-434.

https://doi.org/10.3390/dairy2030034

Academic Editor: Ana Marcia de Sá Guimarães

Received: 16 May 2021

Accepted: 2 August 2021

Published: 6 August 2021

Publisher's Note: MDPI stays neutral with regard to jurisdictional claims in published maps and institutional affiliations.

Copyright: (c) 2021 by the authors. Licensee MDPI, Basel, Switzerland. This article is an open access article distributed under the terms and conditions of the Creative Commons Attribution (CC BY) license (https:// creativecommons.org/licenses/by/ $4.0 /)$.
Abstract: Crimean-Congo hemorrhagic fever (CCHF) is a tick-borne zoonotic disease, endemic in Africa, with a high case fatality rate. There is no efficient treatment or licensed vaccine. This study aimed to determine the prevalence of CCHFV in cattle in extensive grazing systems (both pastoralism and ranching) within the Maasai Mara ecosystem, Nanyuki, and the Ol Pejeta Conservancy in Kenya. We conducted a seroepidemiological study of the sera of 148 cattle from 18 households from the three ecosystems in 2014, 2016, and 2019. Sera from 23 sheep and 17 goats were also obtained from the same households during the same period. Sera were analyzed for the presence of antibodies to CCHFV using the commercially available double-antigen ELISA kit. Overall, 31.5\% CCHFV seropositivity was observed. The prevalence of CCHF was analyzed using a multiple logistic mixed model with main predictors. Risk factors associated with exposure to CCHFV were age $(p=0.000)$ and season $(p=0.007)$. Our findings suggest exposure to CCHFV and point to cattle as likely reservoirs of CCHFV in Kenya. The findings might play a role in providing better insights into disease risk and dynamics where analysis of tick populations in these regions should be further investigated.

Keywords: seroprevalence; vector-borne infections; Crimean-Congo hemorrhagic fever; ruminants; ecosystem; pastoralism; ranching

\section{Introduction}

Crimean-Congo hemorrhagic fever virus (CCHFV) belongs to the order Bunyavirales, family Nairoviridae, genus Orthonairovirus [1]. CCHFV has a wide distribution, occurring in western China, across southern Asia to the Middle East, and in Spain, the Balkans, and Sub-Saharan Africa [2]. CCHFV is the causative agent of Crimean-Congo hemorrhagic fever $(\mathrm{CCHF})$ that has a case fatality ranging from 5 to $80 \%$ [3]. CCHF is classified as a priority disease requiring urgent research and development attention due to its high risk to public health and national security [4]. Humans are susceptible to the virus, with symptoms spanning from nonspecific febrile illness to severe hemorrhagic disease [5]. CCHFV is known to circulate in nature through an enzootic tick-vertebrate-tick cycle [6], with the natural vector being the tick Hyalomma spp [7] although other tick genera have also been shown to transmit CCHFV [6,8]. However, information on the distribution and genetic diversity of CCHFV is quite limited [9]. 
Seroepidemiological studies have implicated animal species, including domestic and wild animals, as natural reservoirs of CCHFV, suggesting their role in the maintenance of the virus. The detection of CCHFV antibodies, especially in domestic animals, may provide evidence of the endemic presence of the virus in certain regions, hence the risk of spillover transmission to humans through contact with infected animal products or bites from infected ticks [10-12]. Surveillance studies have detected CCHFV antibodies in cattle, sheep, goats, horses, donkeys, and camels [13-15]. Domestic animals, especially sheep, are asymptomatic carriers of the virus [16], acting as reservoirs of infection (via ticks) to humans, who suffer significant morbidity [17]. Although domestic equines, sheep, and goats have higher seroprevalence compared to cattle and camels [16], cattle are considered a major reservoir of CCHFV across the world with a significant average seroprevalence of $19 \%$ across 34 countries [16].

In Kenya, CCHFV was first isolated from a farmer in western Kenya in 2000 [18] and, since then, subsequent isolations have been made in diverse tick species sampled from livestock including sheep, cattle, and camels [19,20]. In addition, CCHFV antibodies have been detected in humans in districts close to western Kenya between 2009 and 2012 [21,22].

The role of transhumance in CCHFV transmission, especially in pastoral communities in Kenya, has not been explored. Moreover, there is a lack of data on the extent of livestock exposure, especially cattle, sheep, and goats, to CCHFV. Whether these animals serve as reservoirs of the virus has not been proven despite their close association with humans in whom the virus and the antibodies have been found.

Knowledge of the critical role of livestock in sustaining CCHFV transmission is important in preventing and controlling the virus [23]. Moreover, the determination of whether predisposing factors such as habitat, age, sex, seasonality, husbandry, breed, and socio-demographic factors influence CCHFV transmission is vital for understanding the dynamics of CCHFV transmission. To date, the seroprevalence of CCHFV in livestock in Kenya is still unknown.

Sustainable pastoral development is of great importance for both poverty reduction and environmental management [24], attracting new attention vis à vis emerging interests in resilience and adaptability (e.g., the African Union, 2010) [25,26]. The relationship of pastoralists with their animals is close, which can create a nexus for cross-transmission and cause a public health risk to CCHFV.

The beef and dairy sector are the largest contributors to the agricultural gross domestic product in Kenya [27]. They are also an important source of income, especially in terms of value in the market chain and employment [28] and the main economic activities for rural communities that practice ranching and pastoralism [29-31]. Therefore, CCHFV poses a significant threat to animal trade, considering infected animals may result in livestock embargos which will affect the economy. It also renders farmers at risk of becoming infected due to handling infected animal products or being bitten by infected ticks that had bitten infected animals. We sought to investigate the level of exposure to CCHFV among cattle across three livestock pastoral regions in Kenya and determine associations between risk factors and animal-level seroprevalence.

\section{Materials and Methods}

\subsection{Study Area}

The study area comprised three Kenyan ecosystems: the Maasai Mara ecosystem, Nanyuki, and the Ol Pejeta Conservancy (Figure 1). The Maasai Mara ecosystem is an arid/semi-arid and an important wildlife area in Kenya occupied by Maasai pastoral communities [32]. Nanyuki consists mainly of a rangeland plateau with a varying altitude of 1500 to $2600 \mathrm{~m}$ above sea level. The Ol Pejeta Conservancy is a ranch employing mixedgrazing and close interaction between livestock and human communities. Prolonged dry seasons trigger the movement of people and livestock to river areas where water and pasture are abundant long after the rains have gone. This movement pattern presents an opportunity for the exchange of diverse tick species which may be infected by CCHFV. 


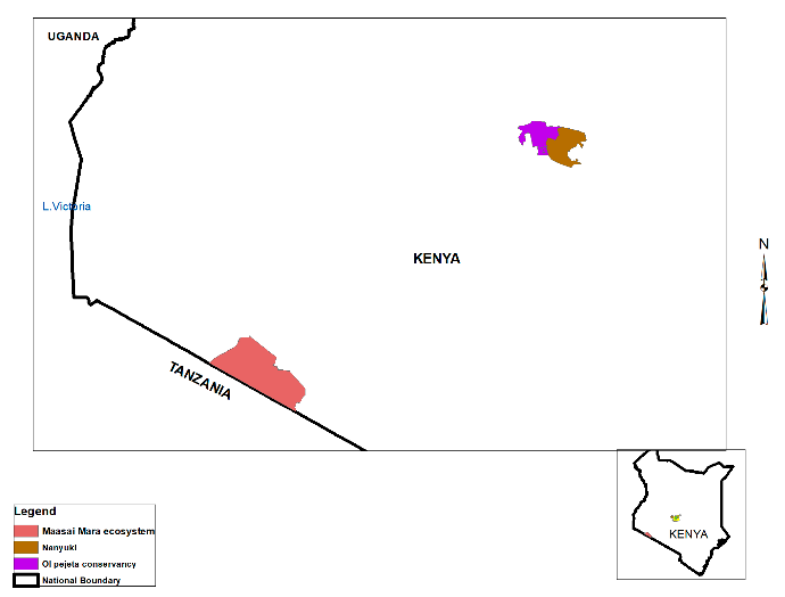

Figure 1. Map of Kenya showing the location of study area and Crimean-Congo hemorrhagic fever (CCHF).

Animal characteristics (age, sex, etc.) and management routines were recorded through a questionnaire at sampling including questions on the type of diseases affecting the animals, whether they have been vaccinated, the type of medicine they give their animals, the reproductive status, and whether they have they given birth or are lactating. Pertaining the animal management practices are pastoralists who practice transhumancenomadism. Farmers self-medicate their animals, do not employ biosecurity measures, and walk for long distances together with their animals in search of water and pasture.

\subsection{Sample Collection}

Samples were collected from animals with no apparent clinical symptoms during the low rain (2014 and 2019) and drought season (2016). In total, 148 serum samples were collected from cattle in households in Maasai Mara $(n=61)$, Nanyuki $(n=9)$, and from herds from the Ol Pejeta Conservancy $(n=78)$. On each household visit, blood samples were taken from three randomly chosen animals. Cattle were randomly sampled from herds from different villages representing the three ecosystems weighted by herd size to assure an even dispersion of the samples in the selected area. A confidence interval of $95 \%$, a margin of error of $5 \%$, an infinite population, an assumed true overall prevalence of 50\% to obtain a maximum sample size, and the sensitivity and specificity of the analytical test were used in the calculations of the sample size.

Vacuitainer ${ }^{\circledR}$ (Beckton, Dickinson and Company, Franklin Lakes, NJ, USA) containers were used to collect $10 \mathrm{~mL}$ of blood from the jugular vein of every individual animal. The collection of blood was carried out in accordance with aseptic procedures. The collected sera were centrifuged at $350 \mathrm{rpm}$ for $15 \mathrm{~min}$ to sediment the erythrocytes. The sera were stored frozen at $-80^{\circ} \mathrm{C}$ at the Veterinary Laboratory in Nairobi pending analysis.

\subsection{Laboratory Testing Procedures}

Serological ID Screen CCHF Double Antigen Multi-Species ELISA (ID.; Vet, Grabels, France) was used according to the manufacturer's instructions. For this kit, the $95 \% \mathrm{CI}$ for sensitivity was $96.8-99.8 \%$, and specificity was $99.8-100 \%$ [28].

ELISA results for the sera of 148 cattle tested were presented in percent probability (PP), which signified that the optical density (OD) obtained for the tested sample was divided by the OD of the positive control of the test and multiplied by 100. As per the manufacturer's instructions, samples presenting a PP less than or equal to $30 \%$ were considered negative, and those greater than $30 \%$ were considered positive [29]. 


\subsection{Data Analysis}

The IgG status was binarized as either positive or negative based on the OD values. This new variable was compared using the Chi-square or Fisher exact test. The 95\% confidence intervals (CIs) for the proportions positive for the virus were estimated.

Logistic regression was performed to understand the predictive factors of CCHFV infection among cattle herds in the study areas. Season and year of sampling were merged in a new variable (seasonality on sampling year) to avoid the lack of fulfillment of categories on the single variables. Geographical location, season at the time of sampling, as well as animal variables, were used as explanatory variables. The household was accounted as a random effect for clustering of observations. Odds ratios, including 95\% confidence intervals, were computed.

The OD distribution was non-normal. It was log-transformed for statistical analysis. Variations in OD levels were examined by the coefficient of variation $(\mathrm{CoV})$ with mean and standard deviation from individuals in the household/site (intra-variation) or among household/site (inter-variation).

All two-way interactions were evaluated one by one for subsequent addition to the model if significant $(p<0.05)$. Model validation was carried out by examining residuals with respect to equal variance and a normal distribution and was found to be valid. Model reduction was based on likelihood ratio (LR) testing at a $5 \%$ level.

Significant differences were determined by $p \leq 0.05$. All statistical analyses were performed using the program STATA Software v. 13 (Stata Corporation, College Station, TX, USA).

\section{Results}

From the total of cattle sampled (148), different indigenous breeds of Kenya were present, namely Improved Boran (50.7\%), Zebu (45.9\%), Ankole (2.03\%), and a residual percentage of Sahiwal (1.35\%). The average household size in Narok County was 5.03 (this concept is only applicable to the Maasai Mara) with varying animal management practices including free-range or communal (47.3\%) and paddocking (52.7\%). The animals' median age was 3 years (range 1-15 years), where females were generally older than males (but with the same median age of 3 years).

From 148 samples analyzed in this study, CCHFV seropositivity was $31.08 \%$. Prevalence varied significantly with geographical sites, with Maasai Mara recording the highest seropositivity (Table 1, Figure 2). Intra-herd variation in CCHF exposure was higher than inter-herd variation (see Table 2), with Maasai Mara having higher intra-household variation. In this specific area, seroprevalence data for each serovar in cattle from mixed pastoral herds are presented in Table 3. For the whole sample, the antibody titers in the serum appeared to have increased over time (see Figure 3).

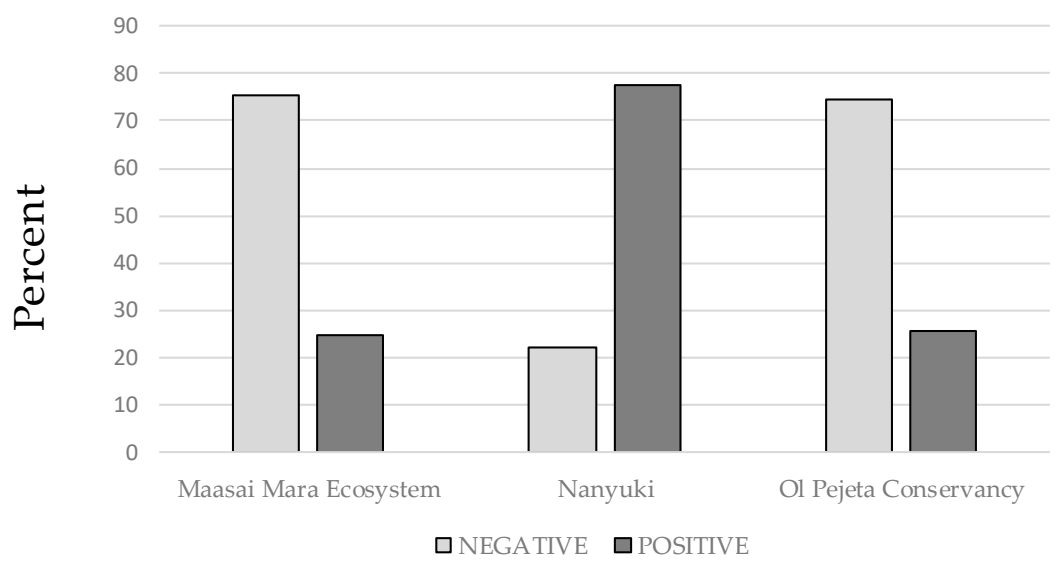

Figure 2. CCHF IgG-positive cases among the sampled cattle by different ecosystems in Kenya. 
Table 1. Animal and other categorical variables of descriptive CCHF serological outcomes, Kenya.

\begin{tabular}{|c|c|}
\hline Variables & Anti-CCHF IgG Prevalence \% \\
\hline \multicolumn{2}{|l|}{ Sex } \\
\hline Female $(n=97)$ & 32.9 \\
\hline Male $(n=51)$ & 27.4 \\
\hline \multicolumn{2}{|l|}{ Breed } \\
\hline Zebu $(n=68)$ & 38.2 \\
\hline Sahiwal $(n=2)$ & 22.6 \\
\hline Ankole $(n=3)$ & 100 \\
\hline Improved Boran $(n=75)$ & 0 \\
\hline \multicolumn{2}{|l|}{ Sampling year } \\
\hline $2014(n=59)$ & 22.0 \\
\hline $2016(n=28)$ & 100 \\
\hline $2019(n=61)$ & 31.1 \\
\hline \multicolumn{2}{|l|}{ Sampling month/season } \\
\hline Low rain $(n=120)$ & 26.6 \\
\hline Dry $(n=28)$ & 100 \\
\hline \multicolumn{2}{|l|}{ Sites } \\
\hline Emarti $(n=7)$ & 57.14 \\
\hline Emboseli $(n=4)$ & 50 \\
\hline Il Poori $(n=4)$ & 0 \\
\hline Irbaan $(n=8)$ & 50 \\
\hline Kamok $(n=23)$ & 47.82 \\
\hline Loigururu $(n=47)$ & 4.2 \\
\hline Mt. Kenya slopes $(n=9)$ & 77.7 \\
\hline Olaimutiak $(n=3)$ & 33.3 \\
\hline Ole Keene $(n=14)$ & 1.53 \\
\hline Ole Seken $(n=7)$ & 33.3 \\
\hline Olekusero $(n=1)$ & 0 \\
\hline Oletontol $(n=2)$ & 0 \\
\hline Orindo $(n=1)$ & 0 \\
\hline Orkiu $(n=5)$ & 0.08 \\
\hline Oseki $(n=2)$ & 0 \\
\hline Scotts $(n=2)$ & 50 \\
\hline Sekenani $(n=3)$ & 33.3 \\
\hline Sirima $(n=6)$ & 100 \\
\hline \multicolumn{2}{|l|}{ Ecosystem } \\
\hline Maasai Mara $(n=101)$ & 24.75 \\
\hline Nanyuki $(n=9)$ & 77.7 \\
\hline Ol Pejeta $(n=78)$ & 25.6 \\
\hline
\end{tabular}

Table 2. Antibodies to CCHFV in serum in cattle in Kenya. Median and interquartile range (IQR) of optical density ratio (ODR) are presented. Variations were examined with coefficient of variation from individuals of the same herd (intra-herd variation; minimum and maximum are presented) or among herds (inter-herd variation).

\begin{tabular}{cccccc}
\hline \multirow{2}{*}{ ODR } & \multicolumn{5}{c}{ Statistical Variables } \\
\cline { 2 - 6 } & $\boldsymbol{n}$ & Median & IQR & Inter-Herd Variation & Intra-Herd Variation \\
\hline Ecosystem & & & & & \\
Maasai Mara & 101 & 0.073 & $0.06 ; 1.09$ & $50.1 \%$ & $12.9-172.8 \%$ \\
Nanyuki & 9 & 2.668 & $2.509 ; 2.729$ & - & $172 \%$ \\
Ol Pejeta & 78 & 0.06 & $0.053 ; 0.301$ & $13.2 \%$ & $102.9-133.6 \%$ \\
\hline
\end{tabular}


Table 3. Number of seropositive and percentage (95\% CI) of animals from 18 single or 13 mixed households sampled in Maasai Mara farms between 2014 and 2019 that were seropositive for CCHF.

\begin{tabular}{cccc}
\hline$n$ & Cattle $(\boldsymbol{n}=\mathbf{6 1})$ & Sheep $(\boldsymbol{n}=\mathbf{2 3})$ & Goat $(\boldsymbol{n}=\mathbf{1 7})$ \\
\hline $\begin{array}{c}\text { Seropositive } \\
\%(95 \% \mathrm{CI})\end{array}$ & 19 & 1 & 5 \\
& $31.0(0.235-0.386)$ & $4.34(-0.046-0.133)$ & $29.4(0.052-0.535)$ \\
\hline
\end{tabular}

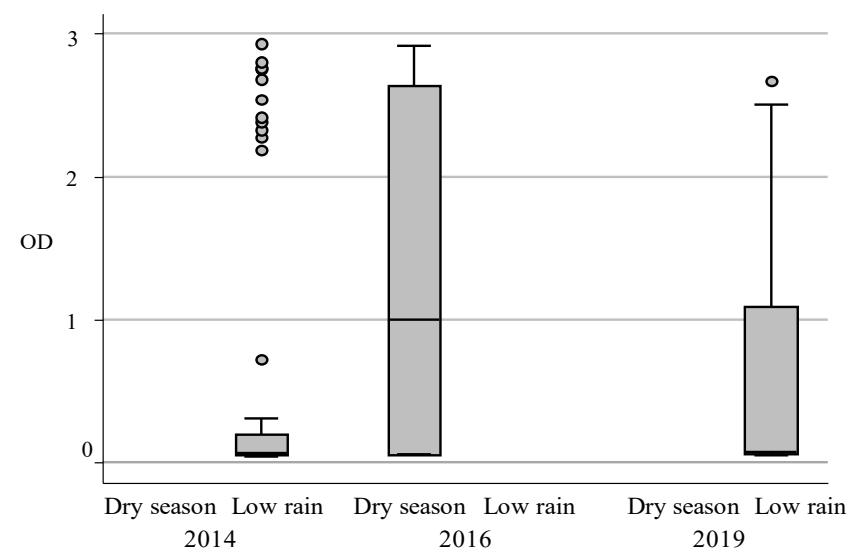

Figure 3. Individual optical density (OD) value by ELISA in different seasons during the sampling years of the surveyed cattle relative to manufacturer's instructions [29]. Bars represent the 95\% confidence interval of the measure.

From the logistic regression analysis (see Table 4), the prevalence of CCHF was associated with increasing age, dry season, and being female. Age differences suggest that the seroprevalence of CCHF is mainly dependent on life exposure. In contrast, low rain was associated with lower odds (see also Figure 3). A tendency for lower odds for males and higher odds in Nanyuki was also observed (Table 4). No interaction terms were significant.

Table 4. Multiple logistic regression analysis for association between studied variables and CCHF serological outcomes in Kenya.

\begin{tabular}{cccc}
\hline Variable & Estimates & OR (95\% CI) & $p$-Value \\
\hline Age ${ }^{1}$ & 0.552 & $1.737(1.405-2.148)$ & 0.000 \\
Sex & & & \\
Female & Baseline & $0.357(0.123-1.038)$ & 0.058 \\
Male & -1.028 & & \\
Season during sampling year & & & 0.007 \\
Dry & Baseline & $0.147(0.0365-0.596)$ & \\
Low rain & -1.912 & & \\
Ecosystem & & & 0.076 \\
Maasai Mara & Baseline & $7.197(0.813-63.65)$ & 0.351 \\
Nanyuki & 1.973 & $1.690(0.560-5.102)$ & \\
Ol Pejeta & 0.525 &
\end{tabular}

${ }^{1}$ Treated as a continuous variable.

\section{Discussion}

Cattle and other domestic animals may serve as reservoirs for CCHFV, which pose a threat to humans $[23,33]$. In Kenya, evidence of CCHFV exposure in humans and diverse tick species has been documented [19-22]. However, the seroprevalence of CCHFV in animals, especially livestock (and despite previous isolation of the virus from ticks attached to cattle and camels), has been undescribed up-to-date. This work is novel since it addresses for the first time the presence of CCHFV antibodies in cattle in Kenya.

The study findings reveal CCHFV exposure in cattle residing in the two major ecosystems including the Ol Pejeta Conservancy and Maasai Mara. The proportion was signifi- 
cantly greater compared to a study conducted in cattle in neighboring Uganda [34] and Zambia [9]. Interestingly, cattle in the Ol Pejeta Conservancy had a lower seroprevalence compared to those in Maasai Mara, and this may be attributed to livestock husbandry practices (see Table 1). For instance, cattle in the Ol Pejeta Conservancy are kept in an enclosed ecosystem entailing a ranch that practices intense spraying of animals at least twice a week with acaricides as a mode of tick control [34,35]. The cattle do not interact with other cattle outside their defined enclosure, hence limiting the chances of acquiring pathogens from other ecosystems, unlike the free-ranging cattle from the Maasai Mara ecosystem [32]. The tick-control strategies in Maasai Mara are variable and on a yearly basis, if they exist [36,37]. The Maasai Mara cattle migrate from one region to another in search of water and pasture, hence the risk of cross-species transfer of pathogens. Cattle interact with other animals, including domestic animals such as goats, sheep, and wildlife, and, in the process, they may acquire or transmit CCHFV to other animal species [36]. Cattle also migrate as far as neighboring Tanzania via the Serengeti National Park where they mix with other herds [38]. Most of the cattle are heavily infested by diverse tick species, including the Hyalomma species that are known to be the main vectors of CCHFV. We believe that the high seroprevalence observed in cattle with the Maasai Mara ecosystem may provide evidence of the endemic presence of the virus and increase the risk to human health, especially to at-risk groups such as herders who interact closely with the livestock. Thus, the different strategies for managing tick populations effectively and the close contact with other livestock species in Maasai Mara might have contributed to the variability observed in this ecosystem.

CCHFV seroprevalence increased with the age of the cattle. This finding is similar to a seroprevalence study performed on domesticated animals in northwestern Senegal [39] and Uganda [40]. While little is known about the association between high CCHFV seroprevalence and increased age, we believe that the CCHFV IgG antibodies increase in older cattle compared to younger cattle due to the increased time for possible exposure of CCHFV. Another possibility may be due to the presence of maternal immunity against $\mathrm{CCHFV}$, which may have had an effect on the low seroprevalence in young animals. In addition, the presence of CCHFV IgG antibodies in young animals may imply a recent infection, which may not have been detected due to lack of awareness and well-established regular and focused surveillance for animals. The odds of females to males contrasts with some previous studies but agrees with others [40]. In our study, the proportion of both sexes was balanced, and females presented the same median, although there were more older female animals than males.

There is no available report of cattle exhibiting symptoms of CCHFV thereby designating their role as potential reservoirs of CCHFV. We believe that cattle could be the most likely source of spillover transmission to humans as they may acquire the virus from tick vectors, which may also transmit the virus to humans (especially those that are in contact with livestock through bites or through infected animal products). Therefore, at-risk human groups, especially those who handle animals and animals' products such as herders, veterinarians, abattoir workers, and farmers, should be aware of the risks, and measures should be put in place to enable them to report, prevent, and control the disease [41-43]. The country depends mostly on the area for beef and dairy products, which requires raising healthy and disease-free animals [44].

CCHFV seroprevalence varied according to seasonality during the sampling year. According to this study, the highest seroprevalence occurred during the period of the dry season. CCHFV outbreaks in other regions in Africa have been associated with weather changes such variations in rainfall, temperature, and humidity, which may influence tick abundance and host-behavior patterns [45]. For example, most cattle in Maasai Mara have to relocate during droughts and hence risk exposure to infected ticks as they search for pasture and water [36,37].

It should be acknowledged that the size of this study is limited. Larger studies should be conducted since the sample size of animals in this study was small, and identifying risk 
factors requires research on representative samples. Another shortcoming is related to the investigation of many putative predictor variables that increase the risk for type II errors (i.e., identifying associations by chance alone). Some variables were embedded in others and, although they are biologically reasonable to check (e.g., breed), should be explored in larger studies. Further studies are needed to include a less biased sample and a higher number of animals.

\title{
5. Conclusions
}

The detection of high prevalence CCHFV-specific antibodies in discrete cattle populations points to CCHFV circulation in the region. The role of environmental and management factors in the transmission of CCHFV among dairy species requires further studies.

\begin{abstract}
Author Contributions: Conceptualization, O.W.L. and I.B.-P.; methodology, V.O., O.W.L. and I.B.-P.; formal analysis, I.B.-P. and V.O., investigation, I.B.-P., O.W.L.; resources, O.W.L., V.O., B.A. and C.A.; data curation, I.B.-P.; writing-original draft preparation, I.B.-P., O.W.L. and V.O.; writing-review and editing, I.B.-P., O.W.L., V.O., B.A., E.K. and C.A.; supervision, I.B.-P., V.O., C.A. and O.W.L.; project administration, O.W.L.; funding acquisition, O.W.L. All authors have read and agreed to the published version of the manuscript.
\end{abstract}

Funding: This research was funded by the Swedish Research Council (2019-04366).

Institutional Review Board Statement: The study was conducted according to the guidelines of the Declaration of Helsinki. The archived samples of cattle were collected during a study approved by the University of Minnesota IRB ID (STUDY00000837) and the Narok County government (NCG/HEALTH/GEN/VOL.1/2).

Informed Consent Statement: Not applicable.

Data Availability Statement: The data presented in this study are available to authorized users. The data are not publicly available due to project IP rules.

Acknowledgments: We appreciate the households in Maasai Mara who willingly participated in this study. We are grateful to Elsie Maina (Kenya Wildlife Service) and Irene Maina (University of Nairobi) for their input in the serological assays.

Conflicts of Interest: The authors declare no conflict of interest.

\section{References}

1. Adams, M.J.; Lefkowitz, E.J.; King, A.M.; Harrach, B.; Harrison, R.L.; Knowles, N.J.; Kropinski, A.M.; Krupovic, M.; Kuhn, J.H.; Mushegian, A.R.; et al. Changes to taxonomy and the International Code of Virus Classification and Nomenclature ratified by the International Committee on Taxonomy of Viruses. Arch. Virol. 2017, 162, 2505-2538. [CrossRef]

2. Bente, D.A.; Forrester, N.L.; Watts, D.M.; McAuley, A.J.; Whitehouse, C.A.; Bray, M. Crimean-Congo hemorrhagic fever: History, epidemiology, pathogenesis, clinical syndrome and genetic diversity. Antivir. Res. 2013, 100, 159-189. [CrossRef] [PubMed]

3. Mertens, M.; Schmidt, K.; Ozkul, A.; Groschup, M.H. The impact of Crimean-Congo hemorrhagic fever virus on public health. Antivir. Res. 2013, 98, 248-260. [CrossRef] [PubMed]

4. Sorvillo, T.E.; Rodriguez, S.E.; Hudson, P.; Carey, M.; Rodriguez, L.L.; Spiropoulou, C.F.; Bird, B.H.; Spengler, J.R.; Bente, D.A. Towards a sustainable one health approach to crimean-congo hemorrhagic fever prevention: Focus areas and gaps in knowledge. Trop. Med. Infect. Dis. 2020, 5, 113. [CrossRef]

5. Mourya, D.T.; Yadav, P.D.; Shete, A.M.; Gurav, Y.K.; Raut, C.G.; Jadi, R.S.; Pawar, S.D.; Nichol, S.T.; Mishra, A.C. Detection, isolation and confirmation of Crimean-Congo hemorrhagic fever virus in human, ticks and animals in Ahmadabad, India, 2010-2011. PLoS Negl. Trop. Dis. 2012, 6, e1653. [CrossRef]

6. Appannanavar, S.B.; Mishra, B. An update on Crimean Congo hemorrhagic fever. J. Glob. Infect. Dis. 2011, 3, 285. [PubMed]

7. Vorou, R.; Pierroutsakos, I.N.; Maltezou, H.C. Crimean-Congo hemorrhagic fever. Curr. Opin. Infect. Dis. 2007, 20, 495-500. [CrossRef]

8. Bell-Sakyi, L.; Kohl, A.; Bente, D.A.; Fazakerley, J.K. Tick cell lines for study of Crimean-Congo hemorrhagic fever virus and other arboviruses. Vector Borne Zoonotic Dis. 2012, 12, 769-781. [CrossRef]

9. Kajihara, M.; Simuunza, M.; Saasa, N.; Dautu, G.; Mori-Kajihara, A.; Qiu, Y.; Nakao, R.; Eto, Y.; Furumoto, H.; Hang'ombe, B.M.; et al. Serologi and molecular evidence for circulation of Crimean-Congo hemorrhagic fever virus in ticks and cattle in Zambia. PLoS Negl. Trop. Dis. 2021, 15, e0009452. [CrossRef]

10. Hoogstraal, H. The epidemiology of tick-borne Crimean-Congo hemorrhagic fever in Asia, Europe, and Africa. J. Med. Entomol. 1979, 15, 307-417. [CrossRef] 
11. Smirnova, S.E.; Nepesova, N.M.; Tachmuradov, G.; Kir'Yanova, A.M.; Chumakov, M.P. Data on Studying Crimean Hemorrhagic Fever in Turkmen SSR. NAMRU-T804. Tr Inst Polio Virus Entsef Akad Med Nauk SSSR. 1971, Volume 19, pp. 86-91. Available online: https: / /agris.fao.org/agris-search/search.do?recordID=US201300336439 (accessed on 5 August 2021).

12. Ceianu, C.S.; Panculescu-Gatej, R.I.; Coudrier, D.; Bouloy, M. First serologic evidence for the circulation of Crimean-Congo hemorrhagic fever virus in Romania. Vector Borne Zoonotic Dis. 2012, 12, 718-721. [CrossRef]

13. Mustafa, M.L.; Ayazi, E.; Mohareb, E.; Yingst, S.; Zayed, A.; Rossi, C.A.; Schoepp, R.J.; Mofleh, J.; Fiekert, K.; Akhbarian, Z.; et al. Crimean-congo hemorrhagic fever, Afghanistan. Emerg. Infect. Dis. 2011, 17, 1940. [CrossRef] [PubMed]

14. Tantawi, H.H.; Shony, M.O.; Al-Tikriti, S.K. Antibodies to Crimean-Congo haemorrhagic fever virus in domestic animals in Iraq: A seroepidemiological survey. Int. J. Zoonoses 1981, 8, 115-120.

15. Pak, T.P. Division into epidemiological districts of Crimean haemorrhagic fever (CHF) in the Tadzhik SSR. Zh Mikrobiol. Epidemiol. Immunobiol. 1972, 12, 112-116.

16. Spengler, J.R.; Bergeron, É.; Rollin, P.E. Seroepidemiological studies of Crimean-Congo hemorrhagic fever virus in domestic and wild animals. PLoS Negl. Trop. Dis. 2016, 10, e0004210. [CrossRef]

17. Ergonul, O.; Tuncbilek, S.; Baykam, N.; Celikbas, A.; Dokuzoguz, B. Evaluation of serum levels of interleukin (IL)-6, IL-10, and tumor necrosis factor- $\alpha$ in patients with Crimean-Congo hemorrhagic fever. J. Infect. Dis. 2006, 193, 941-944. [CrossRef] [PubMed]

18. Dunster, L.; Dunster, M.; Ofula, V.; Beti, D.; Kazooba-Voskamp, F.; Burt, F.; Swanepoel, R.; DeCock, K.M. First documentation of human Crimean-Congo hemorrhagic fever, Kenya. Emerg. Infect. Dis. 2002, 8, 1005. [CrossRef] [PubMed]

19. Sang, R.; Lutomiah, J.; Koka, H.; Makio, A.; Chepkorir, E.; Ochieng, C.; Yalwala, S.; Mutisya, J.; Musila, L.; Richardson, J.H.; et al. Crimean-Congo hemorrhagic fever virus in Hyalommid ticks, northeastern Kenya. Emerg. Infect. Dis. 2011, 17, 1502. [CrossRef]

20. Chiuya, T.; Masiga, D.K.; Falzon, L.C.; Bastos, A.D.; Fèvre, E.M.; Villinger, J. Tick-borne pathogens, including Crimean-Congo haemorrhagic fever virus, at livestock markets and slaughterhouses in western Kenya. Transbound. Emerg. Dis. 2020, 68, 2429-2445. [CrossRef]

21. Lwande, O.W.; Irura, Z.; Tigoi, C.; Chepkorir, E.; Orindi, B.; Musila, L.; Venter, M.; Fischer, A.; Sang, R. Seroprevalence of crimean congo hemorrhagic Fever virus in ijara district, kenya. Vector Borne Zoonotic Dis. 2012, 12, 727-732. [CrossRef]

22. Tigoi, C.; Lwande, O.; Orindi, B.; Irura, Z.; Ongus, J.; Sang, R. Seroepidemiology of selected arboviruses in febrile patients visiting selected health facilities in the lake/river basin areas of Lake Baringo, Lake Naivasha, and Tana River, Kenya. Vector Borne Zoonotic Dis. 2015, 15, 124-132. [CrossRef]

23. Nyataya, J.; Maraka, M.; Lemtudo, A.; Masakhwe, C.; Mutai, B.; Njaanake, K.; Estambale, B.B.; Nyakoe, N.; Siangla, J.; Waitumbi, J.N. Serological Evidence of Yersiniosis, Tick-Borne Encephalitis, West Nile, Hepatitis E, Crimean-Congo Hemorrhagic Fever, Lyme Borreliosis, and Brucellosis in Febrile Patients Presenting at Diverse Hospitals in Kenya. Vector Borne Zoonotic Dis. 2020, 20, 348-357. [CrossRef] [PubMed]

24. Swift, J.J. Ecology of African pastoralist societies by Katherine Homewood. Pastor. Res. Policy Pract. 2011, 1, 5. [CrossRef]

25. African Union. Policy Framework for Pastoralism in Africa: Securing, Protecting and Improving the Lives, Livelihoods and Rights of Pastoralist Communities; African Union: Addis Ababa, Ethiopia, 2013.

26. Chauhan, R.P.; Dessie, Z.G.; Noreddin, A.; El Zowalaty, M.E. Systematic Review of Important Viral Diseases in Africa in Light of the 'One Health' Concept. Pathogens 2020, 9, 301. [CrossRef]

27. Kosgey, I.S.; Mbuku, S.M.; Okeyo, A.M.; Amimo, J.; Philipsson, J.; Ojango, J.M. Institutional and organizational frameworks for dairy and beef cattle recording in Kenya: A review and opportunities for improvement. Anim. Genet. Resour. 2011, 48, 1-11. [CrossRef]

28. Alarcon, P.; Fèvre, E.M.; Muinde, P.; Murungi, M.K.; Kiambi, S.; Akoko, J.; Rushton, J. Urban livestock keeping in the city of Nairobi: Diversity of production systems, supply chains, and their disease management and risks. Front. Vet. Sci. $2017,4,171$. [CrossRef] [PubMed]

29. Mwangi, V.; Owuor, S.; Kiteme, B.; Giger, M. Beef Production in the Rangelands: A Comparative Assessment between Pastoralism and Large-Scale Ranching in Laikipia County. Kenya. Agric. 2020, 10, 399.

30. Kahi, A.K.; Wasike, C.B.; Rewe, T.O. Beef production in the arid and semi-arid lands of Kenya: Constraints and prospects for research and development. Outlook Agric. 2006, 35, 217-225. [CrossRef]

31. Wellington, E.N. Mechanisms of drought management by African pastoralists. In Proceedings of the Animal Production Society of Kenya Symposium, Egerton University, Nakuru, Kenya, 7-8 March 2000; pp. 117-122.

32. Reid, R.S.; Rainy, M.; Ogutu, J.; Kruska, R.L.; Kimani, K.; Nyabenge, M.; McCartney, M.; Kshatriya, M.; Worden, J.; Ng'ang'a, L.; et al. People, Wildlife and Livestock in the Mara Ecosystem: The Mara Count 2002; International Livestock Research Institute: Nairobi, Kenya, 2003.

33. Belobo, J.T.E.; Kenmoem, S.; Kengne-Nde, C.; Emoh, C.P.D.; Bowo-Ngandji, A.; Tchatchouang, S.; Wobessi, J.N.S.; Mikangue, C.A.M.; Tazokong, H.R.; Bebey, S.R.K.; et al. Worldwide epidemiology of Crimean-Congo Hemorrhagic Fever Virus in humans, ticks and other animal species, a systematic review and meta-analysis. PLoS Negl. Trop. Dis. 2021, 15, e0009299. [CrossRef]

34. Amulyoto, M. Human, Cattle and African Buffalo (Syncerus Caffer) Interface in the Ol Pejeta Conservancy. Ph.D. Thesis, Jomo Kenyatta University of Agriculture and Technology, Laikipia County, Kenya, 2020.

35. Amulyoto, M.; Karanja, S.M.; Obanda, V.; Lutomiah, J. Social Structure, Awareness and Practice on Risk of Exposure to Ticks and Tick-Bor ne Diseases in Ol Pejeta Conservancy, Kenya. Int. J. Res. 2018, 5, 713-730. 
36. Keesing, F.; Allan, B.F.; Young, T.P.; Ostfeld, R.S. Effects of wildlife and cattle on tick abundance in central Kenya. Ecol. Appl. 2013, 23, 1410-1418. [CrossRef] [PubMed]

37. Keesing, F.; Ostfeld, R.S.; Okanga, S.; Huckett, S.; Bayles, B.R.; Chaplin-Kramer, R.; Fredericks, L.P.; Hedlund, T.; Kowal, V.; Tallis, H.; et al. Consequences of integrating livestock and wildlife in an African savanna. Nat. Sustain. 2018, 1, 566-573. [CrossRef]

38. Ndeereh, D.; Muchemi, G.; Thaiyah, A.; Otiende, M.; Angelone-Alasaad, S.; Jowers, M.J. Molecular survey of Coxiella burnetii in wildlife and ticks at wildlife-livestock interfaces in Kenya. Exp. Appl. Acarol. 2017, 72, 277-289. [CrossRef]

39. Mangombi, J.B.; Roqueplo, C.; Sambou, M.; Dahmani, M.; Mediannikov, O.; Comtet, L.; Davoust, B. Seroprevalence of CrimeanCongo hemorrhagic fever in domesticated animals in Northwestern Senegal. Vector Borne Zoonotic Dis. 2020, 20, 797-799. [CrossRef] [PubMed]

40. Balinandi, S.; von Brömssen, C.; Tumusiime, A.; Kyondo, J.; Kwon, H.; Monteil, V.M.; Mirazimi, A.; Lutwama, J.; Mugisha, L.; Malmberg, M. Serological and molecular study of Crimean-Congo Hemorrhagic Fever Virus in cattle from selected districts in Uganda. J. Virol. Methods 2021, 290, 114075. [CrossRef] [PubMed]

41. Nabeth, P.; Cheikh, D.O.; Lo, B.; Faye, O.; Vall, I.O.M.; Niang, M.; Wague, B.; Diop, D.; Diallo, M.; Diallo, B.; et al. Crimean-Congo hemorrhagic fever, mauritania. Emerg. Infect. Dis. 2004, 10, 2143. [CrossRef]

42. Karimi, I.; Rostami, J.M.; Chinikar, S.; Ataei, B.; Kasaeian, N.; Jalali, N.; Khosravi, N. Seroepidemiologic survey of Crimean-Congo hemorrhagic fever among slaughters and butchers in Isfahan. J. Isfahan Med. Sch. 2007, 24, 57-62.

43. Athar, M.N.; Baqai, H.Z.; Ahmad, M.; Khalid, M.A.; Bashir, N.; Ahmad, A.M.; Balouch, A.H.; Bashir, K. Crimean-congo hemorrhagic fever outbreak in Rawalpindi, Pakistan, February 2002. Am. J. Trop. Med. Hyg. 2003, 69, 284-287. [CrossRef]

44. Giger, M.; Mutea, E.; Kiteme, B.; Eckert, S.; Anseeuw, W.; Zaehringer, J.G. Large agricultural investments in Kenya's Nanyuki Area: Inventory and analysis of business models. Land Use Policy 2020, 99, 104833. [CrossRef]

45. Ansari, H.; Shahbaz, B.; Izadi, S.; Zeinali, M.; Tabatabaee, S.M.; Mahmoodi, M.; Naieni, K.H.; Mansournia, M.A. Crimean-Congo hemorrhagic fever and its relationship with climate factors in southeast Iran: A 13-year experience. J. Infect. Dev. Ctries. 2014, 8, 749-757. [CrossRef] 